UDC 81'42:328.131

DOI https://doi.org/10.24919/2308-4863.2/30.212295

\author{
Natalia HUMENIUK, \\ orcid.org/ 0000-0002-2275-1396 \\ Candidate of Philological Sciences, \\ Associate Professor at the Department of English Philology and Translation \\ Borys Grinchenko Kyiv University \\ (Kyiv, Ukraine) n.humeniuk@kubg.edu.ua
}

\title{
STYLISTIC ASPECT OF THE JEREMY CORBYN REALIZATION OF THE DISCREDITING OPPONENT TACTICS WITHIN THE UK PRIME MINISTER QUESTION TIME DISCOURSE, 09.04.2019
}

The following work deals with the investigation of the Expressive means and Stylistic devices used by Jeremy Corbyn within the Question Time of the UK Prime Minister discourse, 09.04.19, with the purpose to discredite the UK Prime Minister Boris Johnsons and his Conservative Party as a whole. It is underlined that the Question Time of the UK Prime Minister discourse as a subtype of the parliamentary debates discourse is an aggressive, conflict, confronting communication. It has the global strategic purpose to gain and retain power and the immediate purposes to discredite opponents, to praise the allies, to make self-praising, self-presentation. The long-term struggle of the Conservative and Labour Parties for power in the country determines the confronting nature of the Question Time of the UK Prime Minister discourse in the House of Commons. It is underlined that discrediting means to diminish somebody's authority, significance and importance with the aim to dominate, to be the leader, deprive opponents to be leaders. It is pointed out that Jeremy Corbyn uses the discrediting tactics "Opponent is a liar", "Opponent is non-professional, incompetent". It is stressed that all the used tactics are intertwined and interconnected within the given discourse and aimed to discredite the individual or the collective opponent. It is pointed out that realization of these tactics is possible with the help of the Stylistic devices and Expressive means usage to provoke the addressee attention to the information important for the addressor of message. This is possible to realize by appealing to the feelings and emotions of the addressee, by making the given information stressed and acute with its elements used in the unusual or strong position, by using a great many of provoking elements within the limited space of message. It is stated that Jeremy Corbyn uses a set of Stylistic devices and Expressive means to realize the discrediting opponent tactics: metaphors, detachments, parenthetical sentences, climax, enumerations, repetitions, parallel constructions, epithets, nominative sentences, intensifiers, antithesis, transposition.

Key words: stylistic devices and expressive means, discrediting, discrediting tactics, the Question Time of the UK Prime Minister discourse, constellation, foregrounding of information.

\section{Наталя ГУМЕНЮК, orcid.org/ 0000-0002-2275-1396 кандидат філологічних наук, доиент кафедри англійської філології та перекладу Киїського університету імені Бориса Грінченка (Київ, Україна)n.humeniuk@kubg.edu.ua}

\section{СТИЛІСТИЧНИЙ АСПЕКТ РЕАЛІЗАЦІЇ ДЖЕРЕМІ КОРБІНОМ ТАКТИКИ ДИСКРЕДИТАЦІЇ ОПОНЕНТА В МЕЖАХ ДИСКУРСУ ВІДПОВІДІ НА ЗАПИТАННЯ ПРЕМ'ЄР МІНІСТРОМ СПОЛУЧЕНОГО КОРОЛІВСТВА У ПАРЛАМЕНТІ, 04.09.2019}

\footnotetext{
Подана робота присвячена дослідженню використаних Джеремі Корбіном стилістичних прийомів та засобів у межах дискурсу відповідей на запитання Прем'єр-міністром Сполученого Королівства в парламенті від 04.09.19 р. з метою дискредитувати Прем'єр-міністра Сполученого Королівства Бориса Джонсона та Консервативну партію в иілому. Вказується, щзо дискурс відповідей на запитання Прем'єр-міністром Сполученого Королівства у парламенті як підтип дискурсу парламентських дебатів є агресивною, конфліктною, конфронтуючою комунікаиією. Поданий дискурс має глобальну стратегічну мету отримати та утримати владу та безпосередні иілі дискредитувати опонентів, хвалити союзників, займатися самовихваленням, презентацією самих себе. Довготривала боротьба між Консервативною та Лейбористською партіями за владу в країні позначилась на конфронтуючій природі дискурсу відповідей на запитання Прем'єр-міністром Сполученого Королівства в парламенті в Палаті громад. Підкреслюється, щцо дискредитувати означає зменшити чийсь авторитет, значимість, важливість із метою свого домінування, з метою бути лідером та позбавити опонента можливості бути лідером. Зауважується, шчо Джеремі Корбін використовує дискредитуючі тактики “Опонент - брехун»,
} 
«Опонент не професійний, не компетентний». Підкреслюється, щзо всі використанні тактики в межах поданого дискурсу є пререплетеними та взаємопов'язаними і націлені дискредитувати індивідуального чи колективного опонента. Вказується, щзо реалізачія ичих дискредитуючих тактик можлива за допомогою використання стилістичних засобів та прийомів із метою привернути увагу адресата до важливої для адресанта інформації. Це стає можливим за рахунок апелювання до почуттів та емочій адресата, за рахунок подання цієї інформації як напруженої та гострої з ї̈ елементами у незвичайних або ж сильних позиціях, за рахунок використання сконцентрованої кількості приваблевих елементів в межах лімітованого простору висловлювання. Стверджується, щзо Джеремі Корбін використовує арсенал стилістичних засобів та прийомів у межах дискурсу відповідей на запитання Прем' ср-міністром Сполученого Королівства в парламенті для реалізачії дискредитуючих тактик: метафори, вставні слова, вставні речення, зростання, перерахування, повтор, паралельні конструкції, епітети, номінативні речення, підсилювачі значення, антітеза, транспозиція.

Ключові слова: стилістичні засоби та прийоми, дискредитаџія, дискредитуючі тактики та техніки, дискурс відповідей Прем'єр-міністром Сполученого Королівства в Парламенті, констелячія, висування інформації.

Problem statement. Human communication is characterized either by the cooperative or aggressive, conflict vector of its realization. It means either to respect the others, to cooperate, to co-exist with them or to dominate, to discredite opponents. Any political discourse is characterized by the confronting, conflict nature with the global purpose to gain and retain power. Its realization is possible by the usage of the certain tactics and techniques, by the usage of the Expressive means and Stylistic devices to provoke addressee attention to the given ideas, to appeal to the feelings and emotions of addressee, to represent information important for the addressor.

Literature review. In our work we differentiate the Question Time of the UK Prime Minister discourse as a political discourse (Дьяченко, Халин, 2019; Карасик, 2000; Крячкова, 2019; Шейгал, 1998; Coxall, Robins, 1994; Coxall, Robins 2003; Humeniuk, 2019) and as a subtype of the parliamentary debates discourse (Басюк, 2019; Зернецький, Зернецька, 2004; П'єцух, 2016, 2017). As a newly differentiated discourse, the Question Time of the UK Prime Minister discourse needs further investigation, and this fact makes the scientific research acute.

The aim of the given paper is to investigate Expressive means and Stylistic devices used by the Jeremy Corbyn during the Question Time of the UK Prime Minister on the 4-th of September, 2019, with the aim to discredite opponents - UK Prime Minister Boris Johnsons and the Conservative Party. Method of simple calculation, method of immediate constituents discourse analysis method, pure sampling and comparative method are used to realize the aim of the given work.

The material of the article. The Question Time of the UK Prime Minister (PMQs) as an official process of the UK Prime Minister (PM) answering questions of the MPs (members of UK Parliament) in the House of Commons of the UK Parliament occurs each Wednesday from $12-12.30 \mathrm{p}$. m. It is broadcasted by radio, TV, internet and receives its full transcription in the UK Parliament edition Hansard.
In our work we use the term "Question Time of the UK Prime Minister discourse" as socio-cultural phenomenon of language usage in speech chain with its pragma-communicative purposes oriented on the addressor-addressee communication, where the explicit addressor-addressee communication is represented by the UK Prime Minister and the UK MPs relations in the House of Commons, as well as the implicit addressor-addressee communication is oriented on the communication with the UK voters, who are absent during the given communication in the House of Commons, but potentially present as outsider observer. The communicative purpose of the Question Time of the UK Prime Minister discourse is obvious, to control the in-home and out-of -home activity of the UK Government with the UK Prime Minister at the head. The pragmatic purposes of it are subordinate to the global strategic purpose to gain and retain power in the country and represented as a set of the immediate purposes: 1) to discredite opponents; 2) to praise the allies; 3) to make self-praising, self-presentation (Руженцева, 2004: 11).

So, being the subtype of the parliamentary debates discourse with the features of the political (Шейгал, 1998: 22-28; Рябоконь, 2009: 44) and institutional (Карасик, 2000: 37-64) discourses the Question Time of the UK Prime Minister is an aggressive, conflict, confronting communication.

It's known that discrediting means to diminish somebody's authority, significance and importance (Руженцева, 2004: 21). Any communication based on the discrediting of the opponent communicators is a conflict, aggressive and confronting communication, the aim of which is to dominate, to be leader, to deprive opponents to be leaders.

It is known that long-term confrontation of the Conservative and Labour Parties in the form of struggling for power in the country (Forman, Baldwin, 1998: 209; Рябоконь, 2009: 20) determines the confronting nature of the Question Time of the UK Prime Minister discourse, as the UK Government and the UK Prime Minister Boris Johnsons 
are representatives of the Conservative Party and the Opposition is represented by the Labour Party members with Jeremy Corbyn at the head at the moment of the given discourse realization.

So, we can state that the Question Time of the UK Prime Minister in the House of Commons resembles the fight, the battle between the UK Prime Minister and the MPs from the competitive Labour Party to discredit each other by appealing to the values and wishes, emotions and feelings of the people of the UK community, of the UK voters.

In our work we differentiate the collective opponent (the competitive party as a unity) and the individual opponent (the leaders of the parties, the members of the parties).

We can state, that the discrediting tactics within the Question Time of the UK Prime Minister discourse are focused on the discrediting, on the diminishing the importance and values either of the of the collective opponent (competitive party) or of the individual opponent (leaders and members of the competitive parties).

The analysis of the given discourse shows that the discrediting individual opponent tactics prevails within the Question Time of the UK Prime Minister discourse.

We differentiate the following discrediting tactics used by the head of Opposition in the UK Parliament Jeremy Corbyn to discredite the UK Prime Minister Boris Johnsons and his Conservative Party within the Question Time of the UK Prime Minister discourse into : a) Opponent is a liar; b) Opponent is non-professional, incompetent. The mentioned tactics are not given in pure forms, they are intertwined, interconnected within the Question Time of the UK Prime Minister discourse to realize the global purpose - to gain and to retain power in the country.

In this case, "Opponent is a liar" tactics and "Opponent is non-professional, incompetent" tactics are tactics based on the demonstration of the opponent negative features grounded on the opponent system of values.

This demonstration is possible with the usage of the language units with negative meaning as well as with the usage of Stylistic devices and Expressive means to provoke and arrest the addressee attention by foregrounding information important for the addressor, by influencing the emotions and feelings of addressee.

The analysis of the Question Time of the UK Prime Minister discourse shows that Jeremy Corbyn organizes his discrediting tactics in the form of accusation similar to the court procedure. He presents solid facts, he gives valid arguments, he puts questions to the UK Prime Minister Boris Johnsons giving him chance to prove his innocence, not guilty.

Using the "Opponent is a liar" tactics Jeremy Corbyn tries to accuse the UK Prime Minister Boris Johnsons of being a liar who gives false information about: a) the results of the Brexit negotiations with the $\mathrm{EU} ; \mathrm{b})$ the present and future consequences of Brexit realization.

Using the "Opponent is non-professional, incompetent" tactics Jeremy Corbyn tries to accuse the UK Prime Minister Boris Johnsons of being nonprofessional, incompetent to rule the country, to run the Government, to realize the plans of Brexit.

Jeremy Corbyn organizes his accusation of the UK Prime Minister Boris Johnsons by using a series of valid arguments and facts, by appealing to the authoritative points of view of specialists, politicians, competent organizations and institutions: the Chancellor of Germany and the Taoiseach of Ireland, the Chancellor of the Duchy of Lancaster, the Yellowhammer documents, the British Retail Consortium, the Freedom of Information Act from the Glasgow-based Poverty Alliance, the DWP.

In his messages Jeremy Corbyn not only mentions their authoritative points of view but even he is ready to cite them, to give their quotations:

... British Retail Consortium said that that was "categorically untrue".

All the messages of Jeremy Corbyn within the Question Time of the UK Prime Minister discourse are organized with the same scheme: 1) reaction with serious arguments to the previous Boris Johnsons answer for the question; 2) arguments for the next question to the UK Prime Minister; 3) question itself. All the elements of the given scheme are organized to realize Jeremy Corbyn's plans to discredite the Conservative Party with Boris Johnsons at the head of the UK Government.

We can state that a great amount of questions given by Jeremy Corbyn to the UK Prime Minister Boris Johnsons is rather polite commands to do something than questionery:

So I ask the Prime Minister again: will he publish the Yellowhammer documents in full, so that people can see which foodstuffs are not going to be available, which medicines are not going to be supplied and what will happen given the shortages of vital supplies in every one of our hospitals all over the country?

So, the mentioned above general question sounds like a polite command to show and publish the Yellowhammer documents in full to demonstrate the negative consequences of Brexit in the form of foodstuffs, medicine and vital supplies shortages as a result of the UK Prime Minister and his Cabinet activity. 
The discrediting tactics "Opponent is a liar" is realized by the Jeremy Corbyn repetition of the same word "to hide", "hiding" for several time within the gives discourse to show that the UK Prime Minister gives false information, and this may be dangerous for the UK community:

1. Will the Prime Minister publish that analysis? If he won't, what has he got to hide?

2. He is hiding the facts.

We can state that antithesis is widely used to discredite the UK Prime Minister as a liar. The usage of the antithesis is based on the oppositions "questionanswer", "making progress - no proposals":

1. My first question to the Prime Minister, and no answer given! I asked what proposals had been put to the EU.

2. The Prime Minister and his Cabinet colleagues have said he is making progress. The EU's chief negotiator, the Chancellor of Germany and the Taoiseach of Ireland say that no proposals have yet been made by the UK.

We can assume that Jeremy Corbyn uses a lot of means of negation: no, nothing, none to accuse the UK Prime Minister of giving false information about the Brexit negotiations with the EU and the consequences of Brexit.

The analysis shows that Jeremy Corbyn uses metaphors to realize his plan to discredite the UK Prime Minister Boris Johnsons as a liar:

The negotiations that he talks about are a sham.

The usage of the conceptual metaphor "The negotiations are a sham» makes it possible to transfer the idea of "negotiations" by Boris Johnsons into the idea of «sham», which belongs to the kind of criminal activity. It is known, that criminal activity is associated with hiding its evil deeds and results, where lie is a weapon of criminal activity. So, using this metaphor Jeremy Corbyn is able to influence the UK inhabitants by appealing to their feelings and emotions, as well as by appealing to their mental abilities to make analysis and synthesis of the inappropriate activity of the UK Government with Boris Johnsons at the head.

The usage of epithets makes the Jeremy Corbyn messages colorful and picturesque to arrest the addressee attention to the described facts: undermining negotiations, accurate reports, lengthy peroration...

Parallel constructions of the anaphoric type with the repeated initial part of the sentences " $\mathrm{He}+\mathrm{V}$ " and of the epiphoric type with the repeated final part of the sentences "...know(s) it is not» are used by Jeremy Corbyn to make stress on the information relevant for him with the purpose to discredite the UK Prime Minister Boris Johnsons as a liar:
1. He refuses to publish the Yellowhammer documents. He talks about scaremongering.

2. He knows it is not, and they know it is not.

Ironical effect has information about the Chancellor 's of the Duchy of Lancaster point of view about food prices rising. Jeremy Corbyn stresses:

At the weekend, the Chancellor of the Duchy of Lancaster said that food prices would go up under no deal...

The Prime Minister Boris Johnsons tries to deny the given information about food prices rising:

The Chancellor of the Duchy of Lancaster said absolutely no such thing, and I can tell the right hon ...

The reaction of Jeremy Corbyn to the attempt $\mathrm{s}$ of Boris Johnsons to deny the given information was given in witty and ironical form:

When the Chancellor of the Duchy of Lancaster denied that there would be shortages of fresh food, the British Retail Consortium said that that was "categorically untrue".

To realize the discrediting tactics "Opponent is a liar" Jeremy Corbyn uses parenthetical sentences and detachments to express his attitude to the given information, to give some additional information to the described facts:

1. If the Prime Minister does to the country what he has done to his party in the past 24 hours, a lot of people have a great deal to fear from his incompetence, his vacillation and his refusal to publish known facts - that are known to him -about the effects of a no-deal Brexit.

2. Where does the information come from, other than his office in his Government?

The usage of the parenthetical sentence "that are known to him" and detachment "other than his office in his Government" makes it possible for Jeremy Corbyn to express his attitude to the described facts, to realize his plans to discredite the UK Prime Minister as a liar.

The usage of the detachments within the Question Time of the Prime Minister discourse makes it possible for Jeremy Corbyn not only to express his attitude to the described facts and events, but to represent the chronology of the given events:

1. In six weeks, he has presented nothing to change the previous Prime Minister's deal, which he twice voted against.

2. At the weekend, the Chancellor of the Duchy of Lancaster said that food prices would go up under no deal.

It is known that the idea of Brexit is proposed to realize in the form of leaving the EU with (a deal Brexit, a deal) and without (no deal Brexit, no deal) withdrawal agreement with the EU. The usage 
of the words no deal, a deal as a type of Brexit and the usage of the word combination a great deal used in the direct meaning of the word «deal» makes it possible to use pun or play upon words:

If the Prime Minister does to the country what he has done to his party in the past 24 hours, a lot of people have a great deal to fear from his incompetence, his vacillation and his refusal to publish known facts-that are known to him-about the effects of a no-deal Brexit.

The usage of pun makes the message of Jeremy Corbyn witty, colorful, picturesque to arrest addressee attention, to appeal to their feelings and emotions with the purpose of Boris Johnsons discrediting. Moreover, the given condition sentence is rather emotionally stressed because it sounds like a warning of the harmful consequences of the Boris Johnsons and his Cabinet activity.

The usage of anti-climax in the form of series of words with the first strongest element makes it possible to provoke addressee attention to the enumerated items to show the decrease of quality of the given items as a result of the Conservative Party activity:

The Prime Minister failed to answer my questions about food supplies, about medicine supplies and about the problems in hospitals.

The discrediting tactics "Opponent is nonprofessional, incompetent" is used by Jeremy Corbyn to discredite the UK Prime Minister Boris Johnsons as non-professional, incompetent person to rule the Government and the country, to solve the urgent problems of UK society. That is why the words incapable, incompetence are used several times by Jeremy Corbyn to discredite Boris Johnsons.

The discrediting tactics "Opponent is nonprofessional, incompetent" is realized by Jeremy Corbyn by using antithesis in the form of opposition "question -answer", "to to ask- to answer":

My first question to the Prime Minister, and no answer given! I asked what proposals had been put to the EU. We asked yesterday - many colleagues asked -and he seems utterly incapable of answering. Any rational human being would assume therefore that none have been put and there is no answer.

Within the given example we can observe the usage of the great many of the Stylistic devices and Expressive means within the limited space of message known as constellation.

The usage of the Parallel constructions of the anaphoric type with the repeated "Somebody ( I, we, many colleagues) asked" are used to prove Boris Johnsons's incapability to answer questions. The parenthetic sentence "many colleagues asked" gives the details of he described facts. Nominative sentences "My first question to the Prime Minister", "...and no answer given" on the background of the two-membered sentences sound rather emotionally coloured and stressed to provoke addressee attention. The epithets incapable, rational are used to influence the emotions and feeling of the addressee of information, while intensifier utterly is able to intensify the meaning of the word combination "incapable of answering".

So, all the mentioned above Stylistic devices and Expressive means are used to realize the discrediting plans of Jeremy Corbyn to demonstrate the UK Prime Minister Boris Johnsons as non-professional, incompetent and incapable person for the role of the UK Prime Minister.

We can state that usage of the antithesis based on the opposition "question - no answer" is repeated by Jeremy Corbyn several times within the Question Time of the UK Prime Minister discourse to discredite Boris Johnsons. The number of antithesis given distantly with an emphasis on the time of their occurrence - the past moment (yesterday, in his third day in office), the present moment ( my first question, my question) - are used to prove the Boris Johnsons incapability to occupy the post of the UK Prime Minister as in past, as in present:

1. My first question to the Prime Minister, and no answer given! I asked what proposals had been put to the EU. We asked yesterday - many colleagues asked - and he seems utterly incapable of answering

2. The Prime Minister failed to answer $\underline{m y}$ questions about food supplies, about medicine supplies and about the problems in hospitals.

3. In his third day in office, after five questions from me, we have not had an answer to any of them.

The number of antithesis is given distantly with the rising quantity of the questions which Boris Johnsons is incapable to answer. The number of them is rising from one ("My first question") to three (the enumeration "my questions about food supplies, about medicine supplies and about the problems in hospitals" is used here) and up to five ( the detachment "after five questions from me" is used here), demonstrating the rising incapability of Boris Johnsons to occupy the post of the UK Prime Minister, to solve the urgent problems of the UK community. Its usage is based on the dialectal law idea that rising in quantity may change the quality of the given items - rising incapability of Boris Johnsons to rule the country may be harmful for the whole UK community.

The usage of climax by Jeremy Corbyn is rather effective to discredite the UK Prime Minister Boris Johnsons within the Question Time of the UK Prime Minister discourse: 
Mr Speaker, you don't have to go very far from the portals of this House to see real destitution: people begging and sleeping on the streets; child poverty is up compared with 2010; pensioner poverty is up; and in-work poverty is up.

Climax represented by the enumerated items with rising quality of them (people begging and sleeping on the streets; child poverty, pensioner poverty, and in-work poverty) is able to demonstrate the rising negative consequences of the Boris Johnsons and his Cabinet activity. The discrediting effect of climax usage is intensified by the usage of the enumerated items as elements of the Parallel constructions, which makes it possible to influence the addressee emotions and feelings, as well as to make this information memorable for them.

It is known that non-professional, incompetent persons are frightened of being accused of making errors, mistakes and fails in the process of scrutiny. The idea that Boris Johnsons is frightened of his activity scrutiny is nominated and realized by Jeremy Corbyn by the usage of repetitions "desperate, to avoid scrutiny", by the usage of intensifier "absolutely" to intensify the meaning of the word "desperate", by the usage of detachments "absolutely desperate"; "no plan, no authority and no majority" to give the details of the described facts, of the Boris Johnsons failures as a result of his incompetence, by the usage of climax "no plan, no authority and no majority" to demonstrate the increase of quality of the UK Prime Minister Boris Johnsons incompetence:

$H e$ is desperate - absolutely desperate - to avoid scrutiny. [Interruption.]...I can see why he is desperate to avoid scrutiny: he has no plan to get a new deal - no plan, no authority and no majority.
All the used Expressive means and Stylistic devices within the limited space of Jeremy Corbyn's message during the Question Time of the UK Prime Minister, known as constellation, are able to influence the addressee of information the inhabitants of the UK - with the purpose to discredite the UK Prime Minister Boris Johnsons and his Conservative Party.

\section{Conclusions}

Summing up the material, we can state that realization of Jeremy Corbyn's plans to discredite the UK Prime Minister Boris Johnsons and his Conservative Party during the Question Time of the UK Prime Minister is possible by his successful implementation of the discrediting tactics: "Opponent is a liar", "Opponent is non-professional, incompetent". All the discrediting tactics used by Jeremy Corbyn within the Question Time of the UK Prime Minister discourse are intertwined, interconnected.

Realization of the discrediting tactics presupposes the usage of the Stylistic devices and Expressive means to provoke addressee attention to the information important for the addressor of message by appealing to the feelings and emotions of addressee, by making this information stressed.

To realize the discrediting purposes Jeremy Corbyn uses the following Stylistic devices and Expressive means: metaphors, detachments, parenthetical sentences, climax, enumerations, repetitions, parallel constructions, epithets, nominative sentences, intensifiers, antithesis, transposition.

It is perspective to investigate the pragmacommunicative features of Speaker within theQuestion Time of the UK Prime Minister discourse.

\section{BIBLIOGRAPHY}

1. Басюк Л. М. Дебати в парламентському дискурсі Великої Британії і США : лінгво-прагматичний аспект : автореф. дис. ...канд. філол. наук : 10.02.04 ; Київський університет імені Бориса Грінченка. Київ, 2019.20 с.

2. Дьяченко Н. М., Халін В. В. Комунікативні стратегії в сучасному українському політичному дискурсі. Вісник Житомирського державного університету імені Івана Франка. Сер.: Філологія. 1(89). 2019. С. $56-62$.

3. Зернецька О. В., Зернецький П. В. «Чи прийме парламент нашу подяку?» Дещо про мовний вишкіл британських парламентарів. Віче. 2004. № 9. С. 73-74.

4. Карасик В. И. Этно-культурные типы институционального дисукрса. Этно-культурная специфика речевой деятельности. Сб. обзоров. Москва : ИНИОН РАН, 2000. С. 37-64.

5. Крячкова А. П. Лингопрагматические средства реализации вербальных атак на имидж политических партий Германии : дис. ...канд. филол. наук : 10.02 .04 ; Московский гос. ин-т международных отношений. Москва, 2019. $170 \mathrm{c}$.

6. П'єцух О. І. Емотивність політичного дискурсу парламентських дебатів у Сполученному Королівстві. Науковий вісник Міжнародного гуманітарного університету. Сер.: Філологія. № 25. Т. 2. 2016. С. 103-105.

7. П’єцух О. І. Нормативність політичного дискурсу парламентських дебатів у Сполученному Королівстві Великої Британії та Північній Ірландії. Science and Education a New Dimention. Philololgy. Т ( 31). № 118. 2017. С. 61- 64.

8. Руженцева Н. Б. Дискредитирующие тактики и приемы в российском политическом дискурсе : монография. Уральский гос. пед. ун-т. Екатеринбург, 2004. 294 с.

9. Рябоконь Г. Л. Дискурсивні особливості інтернет публікацій дебатів Британського парламенту : дис. ...канд. філол. наук : 10.01.08 ; Нац. університет «Київо-Могилянська академія». Київ,2009. 276 с.

10. Шейгал Е. И. Структура и граница политического дискурса. Филология- Philologica. Краснодар, 1998. С. 22-29. 
11. Coxall B., Robins L. Contemporary British Politics. NY : Palgrave Macmillan, 1994. P. 509.

12. Coxall B., Robins L., Leach R. Contemporary British Politics. NY : Palgrave Macmillan, 2003. P. 452.

13. Forman F. N., Baldwin N. B. Mastering British Politics. Macmillan, 1996. 478 p.

14. Humeniuk N. H. Pragma-communicative aspects of the Boris Johnson' first speech as a Prime Minister (July, 24, 2019). Закарпатські філологічні студії. В.12. Видавничий дім «Гельветика», 2019. С. 68-74.

15. Humeniuk N. H. Stylistic aspect of the Boris Johnsons' ideological discourse of his first speech as a Prime Minister, 07.24.19. Науковий вісник ДДПУ імені І. Франка. Серія «Філологічні науки». Мовознавство. № 12. 2019. Дрогобич, 2019. C. 39-42.

16. Parliament UK. Commons. 2019-09-04 Debates. Hansard, 2019. URL: https://hansard.parliament.uk/commons/2019-09-04/debates/917B81A6-57F8-48C3-AABE-63224897F16E/Engagements.

\section{REFERENCES}

1. Basiuk L.M. Debaty v parlamentskomu dyskursi Velykoi Brytanii i SSA: linhvo-prahmatychnyi aspekt: avtoreph. dys. ... kand. philol. nauk : 10.02.04. [ Debates in the parliamentary discourse of Great Britain and the United States: linguisticpragmatic aspect: abstract. diss. ... cand. philol. sciences: 10.02.04]. Kyivskyi universitet imeni Borysa Grinchenko. Kyiv, 2019. 20 p.[in Ukrainian].

2. Diachenko N.M., Khalin V.V. Komunikatyvni stratehii v suchasnomu ukraiinskomu politychnomu dyskursi. [Communicative strategies in contemporary Ukrainian political discourse]. Visnyk Zhytomyrskoho derzhavnoho universitetu imeni Ivana Franka. Ser .: Philology. 1 (89). 2019. P.56-62 [in Ukrainian].

3. Zernetska O.V, Zernetsky P.V. Shchi pryime parlament nashu podiaku? Deshcho pro movnyi vyshkil brytanskykh parlamentariv. [«Will Parliament accept our thanks?» Something about the language training of British parliamentarians]. Viche. 2004. № 9. P. 73-74 [in Ukrainian].

4. Karasik V.I. Etno-kulturnye tipy institucionalnogo diskursa. [Ethno-cultural types of the institutional discourse]. Ethno-cultural specificity of speech activity. Coll. reviews. Moskva: INION RAN, 2000, P. $37-64$ [in Russian].

5. Kryachkova A.P. Lingvopragmaticheskie sredstva realizacii verbalnyh atak na imidzh politicheskih partii Germanii : diss. ... kand. philol. nauk : 10.02.04. [Linguo-pragmatic means of the verbal attacks of the political parties image :diss. ... cand. philol. sciences: 10.02.04]. Moscow state institute of the international affairs. Moskva, 2019. 170 p. [in Russian].

6. Pjetsukh O.I. Emotyvnist politychnoho dyskursu parlamentskykh debativ u Spoluchennomu Korolivstvi Velykoi Brytanii. [Emotiveness in the political discourse of the UK Parliamentary debates]. Naukovyi visnyk Mizhnarodnoho humanitarnoho universitetu. Ser. : Philolohiia. Vol. 2 № 25. 2016. P. 103-105[in Ukrainian].

7. Pjetsukh O.I. Normatyvnist politychnoho dyskursu parlamentskykh debativ u Spoluchennomu Korolivstvi Velykoi Brytanii. [Normativity in the political discourse of the UK Parliamentary debates]. Science and Education a New Dimention. Philology. Vol. 31 № 118. 2017. P. 61-64 [in Ukrainian].

8. Ruzhenceva N.B. Diskreditiruiushpie taktiki i priyomy v rossijskom politicheskom diskurse: monographiya. [Discrediting tactics and techniques in Russian political discourse: a monograph]. Uralskij gos. ped. universitet. Ekaterinburg, 2004. 294 p. [in Russian].

9. Riabokon H.L. Dyskursyvni osoblyvosti internet publikatsii debativ Brytanskoho parlamentu: dys. ... kand. philol. nauk; 10.01.08. [Discourse features of the online publications of the British Parliament debates: diss. ... Cand. philol. Sciences: 10.01.08.] Natsionalnyi Universitet «Kyivo-Mohylianska Academiia». Kyiv, 2009. 276 p. [in Ukrainian].

10. Sheigal E.I. Structura i granica politicheskogo diskursa. [The structure and boundary of political discourse]. Philologiya. Krasnodar, 1998. P. 22 -29 [in Russian]. 